\title{
Water Contained Ionic Liquid Medium for Electron Mediator Generation and its Quantification: A Paired Electrolysis Investigation $^{* *}$
}

\author{
G. Muthuraman, K. Kannan, and I. S. Moon* \\ Department of Chemical Engineering, Sunchon National University, 255-Jungang-ro, Suncheon-si, \\ Jeollanam-do, 57922, South Korea \\ *E-mail: ismoon@sunchon.ac.kr
}

doi: $10.20964 / 2018.08 .15$

Received: 26 March 2018 / Accepted: 24 May 2018 / Published: 5 July 2018

The present work aims to use ionic liquid as electrolyte medium to generate reductive electron mediator generation by paired electrolysis. The electrolytic cell potential analysis of 1-Butyl-3 Methyl imidazolium Trifluoromethane sulfonate [BMIM $\mathrm{CF}_{3} \mathrm{SO}_{3}$ ] ionic liquid with water content found minimum cell potential of $6.5 \mathrm{~V}$ found at $18 \mathrm{M}$ water reveals paired electrolysis can be used in generation of electron mediators. Three different types of mediator precursors $\mathrm{Ce}(\mathrm{III})\left(\mathrm{SO}_{4}\right)_{2}$, $\left[\mathrm{Co}(\mathrm{II})(\mathrm{CN})_{5}\right]^{3-}$, and $\mathrm{V}(\mathrm{III})(\text { acetylacetonate })_{3}$ were underwent to generate reductive electron mediator by paired electrolysis. The quantification of reductive electron mediator by potentiometric titration with the help of $\mathrm{H}_{2} \mathrm{O}_{2}$ enables to reuse of the spent ionic liquid. Electrolytic reduction of $\mathrm{V}(\mathrm{III})$ (acetylacetonate) ${ }_{3}$ metal complex in $18 \mathrm{M}$ water contained $\mathrm{BMIM} \mathrm{CF}_{3} \mathrm{SO}_{3}$ under optimized conditions reveals $65 \%$ of $\mathrm{V}(\mathrm{II})\left(\right.$ acetylacetonate) ${ }_{3}$ formation. A well-defined change in reduction efficiency of $\mathrm{V}(\mathrm{III})$ (acetylacetonate) $)_{3}$ from $65 \%$ to $15 \%$ upon addition of $20 \mathrm{mM}$ dichloromethane demonstrates the dichloromethane reduction follows mediated electrochemical reaction (MER). The developed system facilitates to use ionic liquid in generation of electron mediator by paired electrolysis towards degradation of VOCs.

Keywords: Ionic liquid electrolyte, paired electrolysis, galvanostatic mode, electron mediator generation, VOCs

\section{$\underline{\text { FULL TEXT }}$}

(C) 2018 The Authors. Published by ESG (www.electrochemsci.org). This article is an open access article distributed under the terms and conditions of the Creative Commons Attribution license (http://creativecommons.org/licenses/by/4.0/). 